\section{High frequency of chronic lymphocytic leukemia-like low-count monoclonal B-cell lymphocytosis in Japanese descendants living in Brazil}

Chronic lymphocytic leukemia (CLL) is the most common adult leukemia in Western countries. However, it is much less frequent in Asians ${ }^{1,2}$ including in Asians living in Western countries. ${ }^{3}$ At present, it is well-established that virtually every CLL case is preceded by an indolent stage known as monoclonal B-cell lymphocytosis (MBL) of CLL phenotype (CLL-like MBL). ${ }^{4} \mathrm{MBL}$ is categorized as high-count $\left(\mathrm{MBL}^{\text {hi }}\right)$ or low-count $\mathrm{MBL}\left(\mathrm{MBL}^{\mathrm{lo}}\right)$, based on the presence of more versus less than 500 CLL-like clonal $\mathrm{B}$ cells $/ \mu \mathrm{L}$ in peripheral blood $(\mathrm{PB})$, respectively. $\mathrm{MBL}^{\text {hi }}$ cases have a probability of progression to CLL requiring therapy of $\sim 1-2 \%$ patients/year. ${ }^{5}$ In contrast, the clinical significance of $\mathrm{MBL}^{\mathrm{lo}}$ remains to be determined, with rare progression to $\mathrm{MBL}^{\text {hi }}$ and CLL in the medium-term (5-7 years). ${ }^{6}$ CLL-like $\mathrm{MBL}^{\text {lo }}$ is present in $7-14 \%$ individuals from Western adult ( $>40$ years) populations with an overall median (range) MBL clone size of $\sim 1$ cell/ $\mu \mathrm{L}(0.1-10$ cells/ $\mu \mathrm{L})$, based on high-sensitive multiparameter flowcytometry (MFC). In turn, the only study performed in Asian populations reported a lower prevalence of $\mathrm{MBL}$ of $1.3 \%$ in Taiwan, after analyzing 500,000 PB cells/case. ${ }^{8}$ Even though the precise mechanisms (e.g. genetic, environmental or both) that lead to such ethnical differences on the prevalence of CLL still remain unknown, they might be related either to a significantly lower frequency of MBL and/or to a lower rate of malignant transformation of CLL-like MBL to CLL. Therefore, the investigation of the prevalence of CLL-like MBL in Asian populations might contribute to better understand such ethnical differences and to shed light on the pathogenesis of CLL.

Here, we investigated the frequency and characteristics of CLL-like MBL clones among Japanese descendants living in a Western environment through high-sensitive MFC. Overall, 258 healthy adult ( $\geq 40$ years) Japanese descendants living in Sao Paulo (Brazil), without race miscegenation -108 males $(42 \%)$ and 150 females $(58 \%)$, with a median (range) age of 66 years (40-96 years) and no differences in the sex-distribution per age ranges, were randomly invited to participate in the study at the outpatient laboratory sample collection facility of two general hospitals (Hospital Santa Cruz and Hospital S. Paulo/UNIFESP) in Sao Paulo (Brazil) (Online
Supplementary Materials and Methods and Online Supplementary Table S1), and sequentially followed for between 1-5 years after the study had been approved by the corresponding local Ethics Committees. Detection of $\mathrm{MBL}$ cells and enumeration of the main normal residual PB lymphocyte populations were based on high-sensitivity 8-color MFC analysis of $\geq 5 \times 10^{6}$ leukocytes/sample (Online Supplementary Materials and Methods and Online Supplementary Table S2). Whenever enough sample was available, clonal B cells were sorted to investigate CLLassociated cytogenetic abnormalities by interphase fluorescence in situ hybridization (iFISH) and the mutational status of their immunoglobulin heavy chain (IGVH) sequences.

In total, 27 of $258(10.5 \%)$ individuals showed MBL clones, including a greater frequency of males (16 of 108 , $15 \%)$ versus females (11 of $150,7 \%)(P=0.05)$ (Table 1$)$. The frequency of $\mathrm{MBL}$ cases progressively increased with age from $4 \%$ in subjects aged $40-59$ years to $22 \%$ among older ( $\geq 80$ years) adults $(P=0.02)$. Of note, such an increase was significantly higher in males than females (10x vs. $3 \mathrm{x}, P=0.002$ ) (Figure 1; Table 1). Interestingly, the MBL clone size was systematically $<500$ cells $/ \mu L(<0.5$ cells $/ \mu \mathrm{L}$ in $92 \%$ cases) with median (range) counts of 0.12 cells/ $\mu \mathrm{L}$ (0.03-20 cells/ $\mu \mathrm{L}$ ) (Table 1; Online Supplementary Table S3). Of note, MBL clones were significantly larger in men versus women, both in absolute $(P=0.04)$ and in relative numbers $(P=0.02)$, and they progressively increased with age ( $P=0.04$ and $P=0.05$, respectively) in parallel to the greater frequency of MBL (Figure 1). None of the eight CLL-like MBL clones studied carried any CLL-associated cytogenetic abnormality, while 4 of 6 cases in which enough purified MBL cells were available displayed mutated IGHV gene sequences (Online Supplementary Table S4).

Altogether, these results show that, despite the similarly high prevalence of $\mathrm{MBL}^{\text {lo }}$ here reported for the Japanese population living in Sao Paulo and other series of healthy $\mathrm{MBL}^{\mathrm{lo}}$ Caucasians, Japanese presenting with $\mathrm{MBL}^{\mathrm{lo}}$ displayed unique features. These included: i) greater predominance of $\mathrm{MBL}^{\mathrm{lo}}$ in men versus women (men/women ratio of 2 vs. 0.71-1.7); ; ${ }^{7,9}$ ii) almost four-fold smaller $\mathrm{MBL}^{\text {lo }}$ clone sizes (median of 0.12 cells/ $\mu \mathrm{L} v \mathrm{~s} .1$ cell/ $\mu \mathrm{L}$; range: $0.1-34$ cells/ $\mu \mathrm{L}),{ }^{7,10}$ even when high-sensitive MFC methods had been used $;^{7}$ and iii) greater predominance of CLL-like versus non-CLL-like $\mathrm{MBL}^{\text {lo }}$ pheno-

Table 1. Frequency and number of chronic lymphocytic leukemia-like monoclonal B-cell lymphocytosis cells in adult ( $\geq 40$ years) Japanese descendants living in Brazil according to sex and age.

\begin{tabular}{|c|c|c|c|c|c|c|c|c|}
\hline \multirow[b]{2}{*}{$\begin{array}{l}\text { Japanese descendants } \\
\text { living in Brazil }\end{array}$} & \multicolumn{3}{|c|}{ Sex } & \multicolumn{5}{|c|}{ Age range (years) } \\
\hline & Total & Male & Female & $P$ & $(40-59)$ & $(60-79)$ & $(\geq 80)$ & $\mathbf{P}$ \\
\hline Total N. & 258 & 108 & 150 & & $\begin{array}{c}75 \\
(26 \mathrm{M} / 49 \mathrm{~F})\end{array}$ & $\begin{array}{c}156 \\
(72 \mathrm{M} / 84 \mathrm{~F})\end{array}$ & $\begin{array}{c}27 \\
(10 \mathrm{M} / 17 \mathrm{~F})\end{array}$ & \\
\hline $\mathrm{MBL}^{\mathrm{lo}} \mathrm{N} .(\%)$ & $\begin{array}{c}27 \\
(10.5 \%)\end{array}$ & $\begin{array}{c}16 \\
(15 \%)\end{array}$ & $\begin{array}{c}11 \\
(7.3 \%)\end{array}$ & $\begin{array}{c}0.05 \\
(4.1 \%)\end{array}$ & $\begin{array}{c}3 \\
(12 \%)\end{array}$ & $\begin{array}{c}18 \\
(22 \%)\end{array}$ & 6 & 0.02 \\
\hline Clonal B cells in $\mathrm{MB}$ & & & & & & & & \\
\hline $\begin{array}{l}\text { \% MBL cells/total } \\
\text { B cells }\end{array}$ & $\begin{array}{c}0.08 \\
(0.01-20)\end{array}$ & $\begin{array}{c}0.14 \\
(0.02-20)\end{array}$ & $\begin{array}{c}0.05 \\
(0.01-0.20)\end{array}$ & 0.02 & $\begin{array}{c}0.02 \\
(0.01-0.14)\end{array}$ & $\begin{array}{c}0.06 \\
(0.01-0.42)\end{array}$ & $\begin{array}{c}0.26 \\
(0.02-20)\end{array}$ & 0.05 \\
\hline N. clonal B cells/ $\mu \mathrm{L}$ & $\begin{array}{c}0.12 \\
(0.03-20) \\
\end{array}$ & $\begin{array}{c}0.21 \\
(0.04-20) \\
\end{array}$ & $\begin{array}{c}0.09 \\
(0.03-0.4) \\
\end{array}$ & 0.04 & $\begin{array}{c}0.07 \\
(0.03-0.51) \\
\end{array}$ & $\begin{array}{c}0.15 \\
(0.04-0.5) \\
\end{array}$ & $\begin{array}{c}0.32 \\
(0.03-19) \\
\end{array}$ & 0.04 \\
\hline
\end{tabular}

Results expressed as median (range) for continuous variables and as number of cases (percentage) for 495 categorical variables. CLL: chronic lymphocytic leukemia; F: female; M: male; MBL: monoclonal B-cell lymphocytosis; MBL ${ }^{\text {lo }}$ low-count 496 monoclonal B-cell lymphocytosis; N.: number. 
types (98\% vs. $66-85 \%))^{7,9,10}$ associated with, iv) a strikingly high frequency of biclonal $\mathrm{MBL}^{\mathrm{lo}}$ cases (Online Supplementry Table S3) (13 of 27; 48\% vs. 2.6-19\%). The (significantly) smaller MBL clone sizes here detected might contribute to explain the higher frequency of $\mathrm{MBL}$ cases found to have $\geq 2 \mathrm{MBL}$ clones, since oligoclonal expansions of $\geq 2$ unrelated $\mathrm{B}$-cell clones is frequently observed in $\sim 20 \% \mathrm{MBL}^{\mathrm{lo}}$ cases, $^{7}$ particularly among those with lower PB MBL counts $(<150$ cells $/ \mu \mathrm{L})$, whereas its frequency decreases from $\mathrm{MBL}^{\mathrm{lo7}, 9-11}$ to $\mathrm{MBL}^{\text {hi10,11 }}$ and CLL, as clonal B-cell counts in PB increase. In addition, these findings would also support the progressively greater frequency (and size) of $\mathrm{MBL}^{\mathrm{lo}}$ clones during adulthood reported here for the Japanese population living in Brazil. In line with this hypothesis, no cytogenetic alterations were detected in a (small) subset $(n=8 / 27)$ of MBL clones investigated, which also showed a high frequency of mutated IGHV BCR sequences (Online Supplementary Table S4). Similarly to what has been previously reported in follow-up studies of $\mathrm{MBL}^{\text {lo }}$ subjects from European and North-American populations, ${ }^{6,7}$ all CLL-like MBL ${ }^{\text {lo }}$ clones except two, persisted after a 1-5 year follow-up, without significant size variations (data not shown).

Altogether, the above findings suggest a potentially longer time to progression for $\mathrm{MBL}^{\mathrm{lo}}$ in the Japanese versus other (e.g. Caucasian) populations and might contribute to explain the lower prevalence of CLL among Asian populations, including Asian migrants to Western countries. Although direct comparison of the prevalence of $\mathrm{MBL}$ in the Japanese population versus the general (e.g. non-Japanese) population in Brazil would be of utmost interest, the actual prevalence of CLL-like $\mathrm{MBL}^{\text {lo }}$ and CLL in Brazil was not investigated here and still needs to be determined. Despite this, preliminary data suggest that prevalence of CLL in Japanese living in Brazil is also lower than in other ethnic groups living in the same region. Thus, based on the Brazilian CLL registry data, only $0.42 \%$ Japanese patients have been included among all CLL cases registered in the State of Sao Paulo, ${ }^{13}$ a region where 690,600 Japanese descendants live among an overall (age-matched) population of 45,230,000 individuals (1.5\% of the population living in Sao Paulo), further supporting an ethnical/genetic background, more than an environment-related trigger in determining the lower prevalence of CLL in Japan ${ }^{2}$ versus Europe and North-America. However, in a recent study in Taiwan, a lower prevalence of MBL of $1.3 \%$ (4 of 302) has been reported..$^{8}$ Although the lower prevalence of $\mathrm{MBL}$ in this versus our series might be related to the lower sensitivity of the MFC screening technique used (with $5 \times 10^{5}$ cells analyzed per PB sample $v s .>5 \times 10^{6}$ cells in our series) and the slightly lower age of the Taiwanese population, the potential impact of different environmental factors on the occurrence of $\mathrm{MBL}$ in individuals living in Taiwan versus those from a Western country like Brazil, deserves further investigations.

In this regard, in our study clear evidence for early emergence of alterations in the $\mathrm{PB}$ compartments of $\mathrm{T}$ and natural killer (NK) cells was observed, similar to those reported in Caucasian populations. ${ }^{6}$ Thus, the median number of $\mathrm{PB}, \mathrm{T}$ and $\mathrm{NK}$ cells was already significantly increased in $\mathrm{MBL}^{\text {lo }}$ versus non-MBL subjects (Table $2)$. Despite the relatively small sample size $(n=27 \mathrm{MBL}$ cases) and the overall tendency of NK cells to increase with age in non-MBL subjects, such an increase was more pronounced in $\mathrm{MBL}^{\mathrm{lo}}$ versus non-MBL subjects (Online Supplementary Figure S1). These findings are fully in line with similar results found in Caucasian popula-

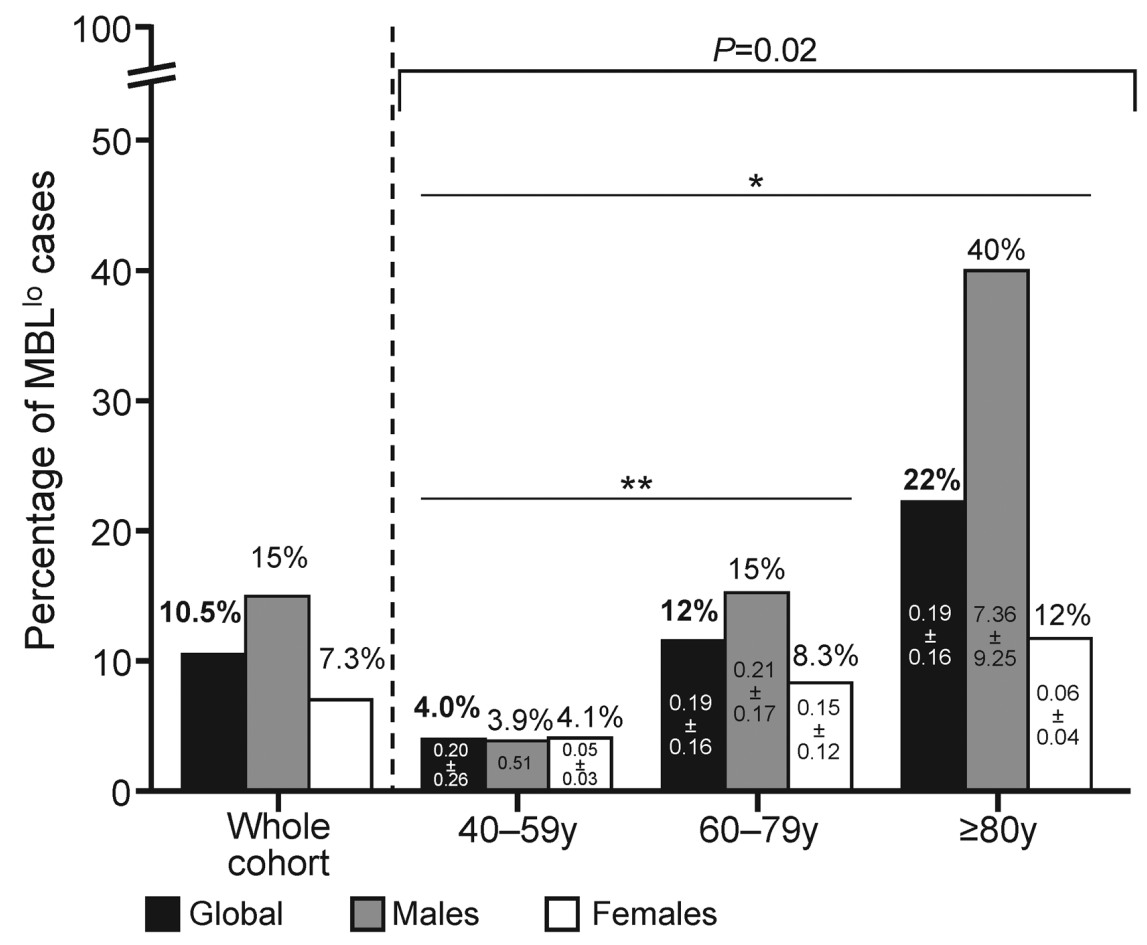

Figure 1. Frequency of low-count monoclonal B-cell lymphocytosis cases $(n=27)$ among 258 healthy adult $(\geq 40$ years) Japanese descendants analyzed, distributed per age group and sex. $* P$-value $=0.004$ for the $40-59$ years versus $\geq 80$ years groups; $* * P$-value $=0.06$ for the $40-59$ years versus $60-79$ years groups. Mean number of peripheral blood circulating clonal B cells/ $\mu \mathrm{L}$ ( \pm 1 standard deviation) is shown inside each bar for $40-59$ years, $60-79$ years and $\geq 80$ years categories, both for males and females. MBL' ${ }^{\text {: }}$ low-count monoclonal B-cell lymphocytosis; y: years. 
Table 2. Distribution of peripheral blood leukocytes, lymphocytes and their T-cell, B-cell and natural killer-cell populations according to the presence versus absence of monoclonal B-cell lymphocytosis in healthy adult ( $\geq 40$ years) Japanese descendants.

\begin{tabular}{|c|c|c|c|c|}
\hline & $\begin{array}{c}\text { Total } \\
n=258\end{array}$ & $\begin{array}{l}\mathrm{MBL}^{10} \\
n=27\end{array}$ & $\begin{array}{c}\text { Non-MBL } \\
n=231\end{array}$ & $\mathbf{P}$ \\
\hline Age (years) & $\begin{array}{c}66 \\
(40-96)\end{array}$ & $\begin{array}{c}70 \\
(42-96)\end{array}$ & $\begin{array}{c}65 \\
(40-93)\end{array}$ & 0.04 \\
\hline N. of leukocytes $\left(\mathrm{x} 10^{9} / \mathrm{L}\right)$ & $\begin{array}{c}5.7 \\
(2.8-14)\end{array}$ & $\begin{array}{c}5.8 \\
(4.4-7.4)\end{array}$ & $\begin{array}{c}5.7 \\
(2.8-14)\end{array}$ & NS \\
\hline N. of lymphocytes (x10\%/L) & $\begin{array}{c}1.8 \\
(0.66-4.6)\end{array}$ & $\begin{array}{c}1.9 \\
(0.79-2.8)\end{array}$ & $\begin{array}{c}1.8 \\
(0.66-4.6)\end{array}$ & NS \\
\hline N. of T cells $\left(\times 10^{\circ} \mathrm{L}\right)$ & $\begin{array}{c}1.1 \\
(0.35-3.2)\end{array}$ & $\begin{array}{c}1.2 \\
(0.56-2.5)\end{array}$ & $\begin{array}{c}1.1 \\
(0.35-3.2)\end{array}$ & 0.05 \\
\hline N. of $\mathrm{CD} 4^{+} \mathrm{T}$ cells $\left(\mathrm{x} 10^{9} / \mathrm{L}\right)$ & $\begin{array}{c}0.7 \\
(0.19-2.8)\end{array}$ & $\begin{array}{c}0.78 \\
(0.39-1.5)\end{array}$ & $\begin{array}{c}0.69 \\
(0.19-2.8)\end{array}$ & NS \\
\hline N. of CD8+ T cells $\left(x 10^{9} / \mathrm{L}\right)$ & $\begin{array}{c}0.29 \\
(0.05-1.2)\end{array}$ & $\begin{array}{c}0.38 \\
(0.10-0.89)\end{array}$ & $\begin{array}{c}0.29 \\
(0.06-1.2)\end{array}$ & NS \\
\hline N. of NK cells $\left(\mathrm{x} 10^{9} / \mathrm{L}\right)$ & $\begin{array}{c}0.27 \\
(0.05-1.1)\end{array}$ & $\begin{array}{c}0.32 \\
(0.12-0.74)\end{array}$ & $\begin{array}{c}0.26 \\
(0.05-1.1)\end{array}$ & 0.002 \\
\hline N. of B cells $\left(x 10^{9} / L\right)$ & $\begin{array}{c}0.19 \\
(0.003-0.84)\end{array}$ & $\begin{array}{c}0.18 \\
(0.05-0.51)\end{array}$ & $\begin{array}{c}0.19 \\
(0.003-0.84)\end{array}$ & NS \\
\hline N. of plasma cells $\left(x 10^{9} / \mathrm{L}\right)$ & $\begin{array}{c}3.4 \\
(0.12-79)\end{array}$ & $\begin{array}{c}2.0 \\
(0.23-18)\end{array}$ & $\begin{array}{c}3.4 \\
(0.12-79)\end{array}$ & NS \\
\hline B-cell subsets & $\begin{array}{c}\text { Total } \\
n=143\end{array}$ & $\begin{array}{l}M B L^{10} \\
n=21\end{array}$ & $\begin{array}{c}\text { Non-MBL } \\
n=122\end{array}$ & $P$ \\
\hline N. of immature B cells (x106/L) & $\begin{array}{c}11 \\
(0.003-147)\end{array}$ & $\begin{array}{c}12 \\
(0.54-76)\end{array}$ & $\begin{array}{c}11 \\
(0.003-147)\end{array}$ & NS \\
\hline N. of naïve B cells (x106/L) & $\begin{array}{c}144 \\
(1.7-714)\end{array}$ & $\begin{array}{c}111 \\
(23-373)\end{array}$ & $\begin{array}{c}150 \\
(1.7-714)\end{array}$ & NS \\
\hline N. of memory B cells $\left(x 10^{6} / \mathrm{L}\right)$ & $\begin{array}{c}38 \\
(1.9-130)\end{array}$ & $\begin{array}{c}42 \\
(14-129)\end{array}$ & $\begin{array}{c}38 \\
(1.9-130)\end{array}$ & NS \\
\hline N. of unswitched memory B cells (x106/L) & $\begin{array}{c}12 \\
(0.48-80)\end{array}$ & $\begin{array}{c}15 \\
(4.0-37)\end{array}$ & $\begin{array}{c}12 \\
(0.48-80)\end{array}$ & NS \\
\hline N. of switched memory B cells (x106/L) & $\begin{array}{c}26 \\
(1.0-94) \\
\end{array}$ & $\begin{array}{c}27 \\
(7.0-93) \\
\end{array}$ & $\begin{array}{c}26 \\
(1-94) \\
\end{array}$ & NS \\
\hline
\end{tabular}

Results expressed as median values (range); B-cell subsets expressed in cells x106/L. MBL: monoclonal B-cell lymphocytosis; NK: natural kiler; N.: number; NS: not statistically significantly different $(P>0.05)$.

tions showing greater NK- and T-cell numbers in $\mathrm{PB}$ of $\mathrm{MBL} .{ }^{6}$ Likewise, similar anti-cytomegalovirus (anti-CMV) and anti-Epstein-Barr virus (anti-EBV) antibody (Ab) titers were found in $\mathrm{MBL}^{\text {lo }}$ versus non-MBL Japanese (Online Supplementary Table S5 and Supplementary Figure S2), as previously described for $\mathrm{MBL}^{\text {lo }}$ Caucasians. ${ }^{14}$

Altogether, these findings suggest that similar (i.e. common) genetic (e.g. sex) and/or environmental factors (e.g. multiple diverse antigenic determinants) might be involved in the earliest stages of development of (biclonal/oligoclonal) MBL expansions in both the Japanese and Western European/North-American populations., ${ }^{9} 15$ However, expansion and transformation of such CLLlike $\mathrm{MBL}^{\text {lo }}$ clones into $\mathrm{MBL}^{\text {hi }}$ and CLL would require additional genetic and/or environmental triggers, including those involved in acquisition of CLL-associated genetic alterations, $^{15}$ that might differ among Asian and Caucasian populations.

In summary, here we show that Japanese descendants ( $\geq 40$ years) living in Sao Paulo (Brazil) display a similar frequency of MBL to that found among Western
Caucasian populations, at the expense of smaller $\mathrm{MBL}^{\text {lo }}$ clones, and higher frequency of oligoclonality, suggesting earlier stages of development with potentially lower rates of progression to $\mathrm{MBL}^{\text {hi }}$ and CLL. Further studies in larger cohorts of Japanese (or Asian) versus non-Japanese control populations living in the same -as well as distinct geographical regions- are necessary to gain insight into the potential genetic and microenvironmental factors that determine these differences.

\section{Mariane de Faria-Moss, ${ }^{1 *}$ Mihoko Yamamoto, ${ }^{*}$}

Celso Arrais-Rodrigues, ${ }^{1}$ Ignacio Criado, ${ }^{2}$ Caio Perez Gomes, ${ }^{1,3}$ Maria de Lourdes Chauffaille, ${ }^{1}$ Matheus Vescovi Gonçalves, ${ }^{1}$ Eliza Kimura, ${ }^{1}$ Efstathios Koulieris, ${ }^{2}$ Fabio Borges, ${ }^{1}$

Guilhermo Dighiero, ${ }^{4}$ Joao Bosco Pesquero, ${ }^{3}$ Julia Almeida ${ }^{2 \#}$ and Alberto Orfao ${ }^{2 \#}$

${ }^{*} M d F M$ and $M Y$ contributed equally as co-first authors.

"IA and $A O$ are co-senior authors.

${ }^{1}$ Division of Hematology, Universidade Federal de São Paulo (EPM-UNIFESP), Sao Paulo, Brazil; ' Cancer Research Center, 
Cytometry Service (NUCLEUS) and Department of Medicine, University of Salamanca, Instituto de Investigación Biomédica de Salamanca (IBSAL) and CIBERONC CB16/12/00400 (Centro de Investigación Biomédica en Red de CÁNCER), Salamanca, Spain; ${ }^{3}$ Department of Biophysics (EPM-UNIFESP), Sao Paulo, Brazil and "Institut Pasteur of Montevideo, Montevideo, Uruguay

Correspondence:ALBERTOORFAO-orfao@usal.es

MIHOKOYAMAMOTO - yamamoto@unifesp.br

doi:10.3324/haematol.2019.230813

Funding: FAPESP (proc 2010/17668-6) and CAPES (scholarship MFF) from Brazil; RD12/0036/0048, CB16/12/00400 (CIBERONC), PI12/00905-FEDER and PI17/00399-FEDER, Instituto de Salud Carlos III, Ministerio de Economia y Competitividad, (Madrid, Spain and FONDOS FEDER).

Acknowledgments: we thank all participants of the study from the Sao Paulo Japanese community, Hospital Santa Cruz and members of DASA, INFAR/UNIFESP (Confocal and Flow Cytometry Facility, att. Edgar Julian Gamero-Parede), Maria L. Martino Lee, Maria M R. Oliveira, Fabio Pinotti Guirao, Akemi Kuroda Chiba, Regina A. Mariya, Rosemary A.G. Giacomussi and Verena Pfister (for technical assistance), Maria Stella Figueiredo and Vinicius Campos Molla (for biostatistical programming support), Marçal C. Andrade-Silva and Marcelo P. Lacerda (for the recruitment of volunteers at Hospital Santa Cruz).

Information on authorship, contributions, and financial \& other disclosures was provided by the authors and is available with the online version of this article at $W$ Ww. haematologica.org.

\section{References}

1. Scarfò L, Ferreri AJM, Ghia P. Chronic lymphocytic leukaemia. Crit Rev Oncol Hematol. 2016;104:169-182.

2. Chihara D, Ito H, Matsuda T, et al. Differences in incidence and trends of haematological malignancies in Japan and the United States. Br J Haematol. 2014;164(4):536-545

3. Yang S-M, Li J-Y, Gale RP, Huang X-J. The mystery of chronic lymphocytic leukemia (CLL): Why is it absent in Asians and what does this tell us about etiology, pathogenesis and biology? Blood Rev. 2015;29(3):205-213

4. Landgren O, Albitar M, Ma W, et al. B-cell clones as early markers for chronic lymphocytic leukemia. N Engl J Med. 2009;360 (7):659-667.

5. Rawstron AC, Bennett FL, O'Connor SJ, et al. Monoclonal B-cell lymphocytosis and chronic lymphocytic leukemia. N Engl J Med. 2008;359(6): 575-583.

6. Criado I, Rodriguez-Caballero A, Gutierrez ML, et al. Low-count monoclonal B-cell lymphocytosis persists after seven years of follow up and is associated with a poorer outcome. Haematologica. 2018;103(7):1198-1208.

7. Nieto WG, Almeida J, Romero A, et al. Increased frequency (12\%) of circulating chronic lymphocytic leukemia-like B-cell clones in healthy subjects using a highly sensitive multicolor flow cytometry approach. Blood. 2009;114(1):33-37.

8. Wu SJ, Lin CT, Lin SC, et al. Similar epidemiological trends of preneoplastic precursors and their respective lymphoid malignancies in Taiwan. Ann Hematol. 2016;95(10)1727-1729.

9. Dagklis A, Fazi C, Sala C, et al. The immunoglobulin gene repertoire of low-count chronic lymphocytic leukemia (CLL)-like monoclonal B lymphocytosis is different from CLL: diagnostic implications for clinical monitoring. Blood. 2009;114(1):26-32.

10. Vardi A, Dagklis A, Scarfo L, et al. Immunogenetics shows that not all $\mathrm{MBL}$ are equal: the larger the clone, the more similar to CLL. Blood. 2013;121(22):4521-4528.

11. Shim YK, Rachel JM, Ghia P, et al. Monoclonal B-cell lymphocytosis in healthy blood donors: An unexpectedly common finding. Blood. 2014;123(9):1319-1326.

12. Fazi C, Scarfò L, Pecciarini L, et al. General population low-count CLL-like MBL persists over time without clinical progression, although carrying the same cytogenetic abnormalities of CLL. Blood. 2011;118(25):6618-6625.

13. Goncalves MV, Rodrigues CA, Lorand Metze IGH, et al. Chronic lymphocytic leukemia in Brazil: A retrospective analysis of 1903 cases. Am J Hematol. 2017;92(8):E171-E173.

14. Criado I, Muñoz-Criado S, Rodríguez-Caballero A, et al. Host virus and pneumococcus-specific immune responses in high-count monoclonal B-cell lymphocytosis and chronic lymphocytic leukemia: Implications for disease progression. Haematologica. 2017;102(7):1238-1246.

15. Henriques A, Rodriguez-Caballero A, Criado I, et al. Molecular and cytogenetic characterization of expanded B-cell clones from multiclonal versus monoclonal B-cell chronic lymphoproliferative disorders. Haematologica. 2014;99(5):897-907. 